\title{
A new species of Speonemadus from Portugal, with the revision of the escalerai-group (Coleoptera, Leiodidae)
}

\author{
Ana Sofia P.S. REBOLEIRA ${ }^{1, *}$, Javier FRESNEDA ${ }^{2,3}$ \& José Maria SALGADO ${ }^{4}$ \\ ${ }^{1}$ Natural History Museum of Denmark (Zoological Museum), \\ University of Copenhagen, Universitetsparken 15, DK-2100 København Ø, Denmark. \\ ${ }^{2}$ Ca de Massa, 25526 Llesp-El Pont de Suert, Lleida, Spain. \\ ${ }^{3}$ Museu de Ciències Naturals (Zoologia), Passeig Picasso s/n, 08003 Barcelona, Spain. \\ ${ }^{4}$ Departamento de Ecologia y Biologia Animal, Universidad de Vigo, \\ Campus Lagoas-Marcosende, 36310 Vigo, Spain. \\ * Corresponding author: sreboleira@ua.pt \\ 2Email: ffresned@gmail.com \\ ${ }^{4}$ Email: jmsalgadocostas@uvigo.es \\ ${ }^{1}$ urn:1sid:zoobank.org:author:338DE845-4839-4EF5-B684-587C021F076C \\ ${ }^{2}$ urn:Isid:zoobank.org:author:26EC3E27-DD32-4E86-BC2F-868835FBD5E8 \\ ${ }^{4}$ urn:lsid:zoobank.org:author:091C647B-1BA1-4058-B949-01F50E9B3742
}

\begin{abstract}
Over recent years, intense field work in caves of Portugal has provided new data on the distribution of subterranean Iberian leiodid beetles. Speonemadus algarvensis sp. nov. is described from caves of southern Portugal. The new species is included in the Speonemadus Jeannel, 1922 escaleraigroup (Cholevinae; Anemadini). All species of the S. escalerai-group are revised and S. breuili (Jeannel, 1922 ) is resurrected as a valid species. A key to identify the species of the $S$. escalerai-group is provided and the distinctive characters are illustrated. The distribution of all species of the group is mapped with new data together with biogeographic considerations.
\end{abstract}

Key words. Beetles, subterranean, troglobiont, karst, caves, Speonemadus.

Reboleira A.S.P.S., Fresneda J. \& Salgado J.M. 2017. A new species of Speonemadus from Portugal, with the revision of the escalerai-group (Coleoptera, Leiodidae). European Journal of Taxonomy 261: 1-23. http://dx.doi. org/10.5852/ejt.2017.261

\section{Introduction}

The genus Speonemadus Jeannel, 1922 has been the subject of a comprehensive review by Giachino \& Vailati (1993), who established Hormosacus Jeannel, 1936 as a synonym of Speonemadus, due to close structural homology between morphological characters of the aedeagus.

Speonemadus comprises 10 taxa divided into four species groups, seven of which are distributed in the Iberian Peninsula (Giachino \& Vailati 1993; Perreau 2000; Salgado et al. 2008). 
Recent intense fieldwork in Portuguese caves has provided abundant material of troglobiont beetles (Reboleira 2007; Reboleira et al. 2009, 2010a, 2011b; Reboleira \& Ortuño 2011). Among this material, a new species of Speonemadus belonging to the escalerai-group was found. Currently, this species group comprises three Iberian species: Speonemadus angusticollis (Kraatz, 1870), S. bolivari (Jeannel, 1922) and S. escalerai (Uhagón, 1898).

We describe a new southwestern Iberian species of Speonemadus, that colonizes caves of southern Portugal, and revise all species of the escalerai-group. We also resurrect Speonemadus breuili (Jeannel, 1922) as a valid species.

\section{Material and methods}

Specimens were collected with baited pit fall traps and by active searching in several caves of the Iberian Peninsula (Reboleira 2012).

Male genitalia were extracted and immersed in a $10 \% \mathrm{KOH}$ solution for six hours and then dehydrated with a series of ethanol transfers $(60 \%$ to $96 \%)$, followed by a xylene immersion for 12 hours and final mounting in Canada balsam.

The general external morphology of the specimens was photographed with a stereo microscope Olympus SZX16, the aedeagus with an Olympus CH; both using an Olympus C5060WZ camera; photos were combined using CombineZP. For scanning electron microscopy, specimens were critical point dried in a Tousimis Autosamdi 815, series A, and mounted on aluminium stubs, coated with platinum/palladium and studied in a JEOL JSM-6335F scanning electron microscope. Images were processed with Adobe Photoshop CS6.

Habitus length was measured from the apex of the labrum to the tip of the elytra. Mean measurements in Table 1 correspond to six specimens of each sex.

\section{Institutional abbreviations}

The material is deposited in the following collections:

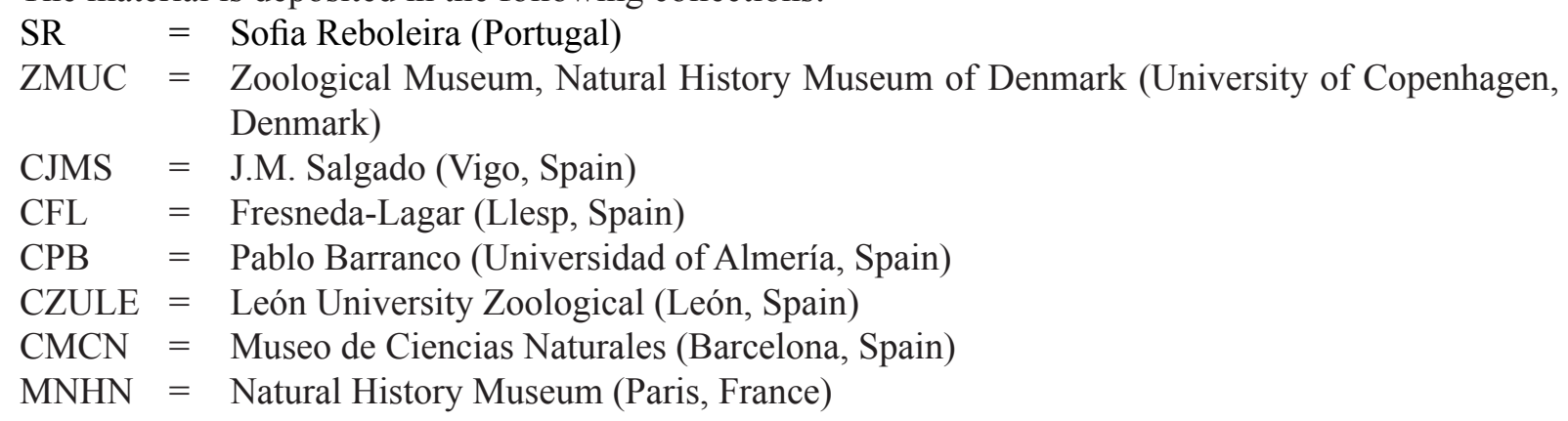

\section{Results}

Class Insecta Linnaeus, 1758

Order Coleoptera Linnaeus, 1758

Family Leiodidae Fleming, 1821

Subfamily Cholevinae Kirby, 1837

Tribe Anemadini Hatch, 1928 
Genus Speonemadus Jeannel, 1922

Speonemadus escalerai-group; "Gruppo escalerai" sensu Giachino \& Vailati 1993: 205.

Representatives of this group are characterized by a body length between 3.9 to $5.0 \mathrm{~mm}$ and have a slightly transverse pronotum (Figs 6-15); the anterior tibia of the males is compressed towards the apical half and has a keel with different shapes on the dorsal edge (Figs 16-20); elytra have a rounded apex in males and a notched one in females. The median lobe of the aedeagus is elongated and bottleshaped in dorsal view (Figs 21-25) and the inner sac lacks a ventral tooth in the apical region of the middle lobe and has two long parallel rows of fine spines and teeth (Figs 23-24).

All species of the group have similar color patterns, the same antennal shape and development of the membranous wings in both sexes, as well as similar genital segments and aedeagi in males, and similar $7^{\text {th }}$ and $8^{\text {th }}$ urosternites and spermatheca of females.

The life-style of this group is mostly subterranean, they are frequently found under stones or in leaf litter in forests and in caves, walking in bat guano or in the subterranean substrate.

\section{Key to the species of the Speonemadus escalerai-group}

Note to the key: diversification of the species of the escalerai-group is likely to be recent (see below "Speciation and biogeography"). Therefore, morphological differences are not particularly visible and a combination of characters should be used for species recognition. All species and both sexes of the "escalerai" group show a similar coloration, shape of the antenna, development of membranous wings, genital segment in the male aedeagus and $7^{\text {th }}$ and $8^{\text {th }}$ uroventrites, as well as spermatheca of the females. Females have no characters to distinguish between species, which also occurs in other genera of the Leiodidae, e.g., Colon Herbst, 1797. Only females of S. angusticollis can be separated from other species by the shape of the pronotum, being the only one with a bell-shape, as in males. Therefore, in this species group only males provide distinctive characters useful for identification. These characters are identified in all key items and constitute the basis of specific differentiation.

1. Male with a high protibial keel, with the highest point around middle of the tibia (Figs 16, 18, 20) ...2

- Male with a lower protibial keel, with the highest point at the basal third of the tibia (Figs 17, 19) ...4

2. Protibial keel with sharp vertex and slightly lobed from the margin to the base (Fig. 20); elytra sculpture and pronotum granularity poorly marked; pronotum sexually dimorphic (Figs 14-15) .....

S. escalerai (Uhagón, 1898)

- Protibial keel with a slightly sharp vertex and linear margin to the base (Figs 16, 18); elytra sculpture and pronotum with well marked granularity; pronotum not sexually dimorphic (Figs 6-7, 10-11) ...3

3. Body size generally small (male length around $4.2 \mathrm{~mm}$ ); protibial keel with sharp apex and basal part of the protibia with a wide keel (Fig. 18); $8^{\text {th }}$ antennomere around $1.5 \times$ longer than wide and $4^{\text {th }}$ one length different from $5^{\text {th }}$ and $7^{\text {th }}$ antennomeres in both sexes $\ldots$. S. bolivari (Jeannel, 1922)

- Body size generally larger (mean male length around $4.8 \mathrm{~mm}$ ); protibial keel with rounded apex and the basal area of the protibia with a wider keel (Fig. 16); $8^{\text {th }}$ antennomere more than $1.4 \times$ longer than wide and $4^{\text {th }}$ antennomere equal or almost equal in length to $5^{\text {th }}$ and $7^{\text {th }}$ antennomeres in both sexes

S. algarvensis sp. nov.

4. Upper margin of protibial keel long, linear medially (Fig. 17); $8^{\text {th }}$ antennomere slightly less than $1.5 \times$ longer than wide, and $4^{\text {th }}, 5^{\text {th }}$ and $7^{\text {th }}$ antennomeres of unequal length in both sexes $\ldots .$.

S. angusticollis (Kraatz, 1870)

- Upper margin of protibial keel short, curved medially (Fig. 19); $8^{\text {th }}$ antennomere more than $1.5 \times$ longer than wide and $4^{\text {th }}, 5^{\text {th }}$ and $7^{\text {th }}$ antennomeres of almost equal length in both sexes

S. breuili (Jeannel, 1922) 
Speonemadus algarvensis sp. nov. urn:Isid:zoobank.org:act:5CFDCE6C-71CE-4763-89BD-B8A68E945A80

Figs 1, 6-7, 16, 21, 26-31

\section{Diagnosis}

A species of Speonemadus with a total length of $4.0-4.9 \mathrm{~mm}$, belonging to the escalerai-group, and with typical features of the group; characterised by having the $2^{\text {nd }}, 4^{\text {th }}, 5^{\text {th }}$ and $7^{\text {th }}$ antennomeres equal or subequal in length; a slightly transverse and hexagonal pronotum; and a long, raised and elevated protibial keel in males, with the apex moderately sharp.

\section{Etymology}

The species epithet is derived from the type locality, the southernmost province of Portugal, the Algarve.

\section{Material examined}

\section{Holotype}

PORTUGAL: ${ }^{\lambda}$, Algarve, Loulé, Gruta do Vale Telheiro, coordinates: WGS 84: $37^{\circ} 10^{\prime} 14^{\prime \prime} \mathrm{N}$, $008^{\circ} 02^{\prime} 06^{\prime \prime}$ W, 29 Dec. 2009, S. Reboleira leg. (ZMUC number 00036257).

\section{Paratypes}

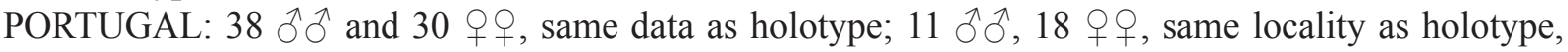

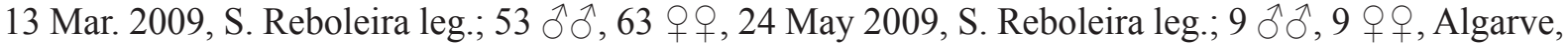
São Brás de Alportel, Algarão do Remexido, 15 Mar. 2009, S. Reboleira leg.; 1 +, same locality, 23 May

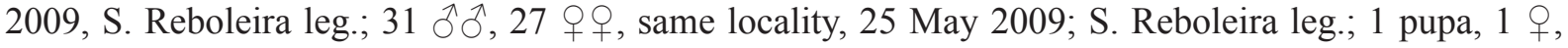
same locality, 5 Sept. 2009, S. Reboleira leg.; 3 ふરત, 3 우, same locality, 29 Dec. 2009, S. Reboleira leg.; 4 우, Algarve, Moncarapacho, Gruta da Senhora, 29 Dec. 2009, S. Reboleira leg.; 1 ô, same locality, 24 May 2009, S. Reboleira leg. (SR, CASR, CJMS, CZULE, CFL, CPB, ZMUC).
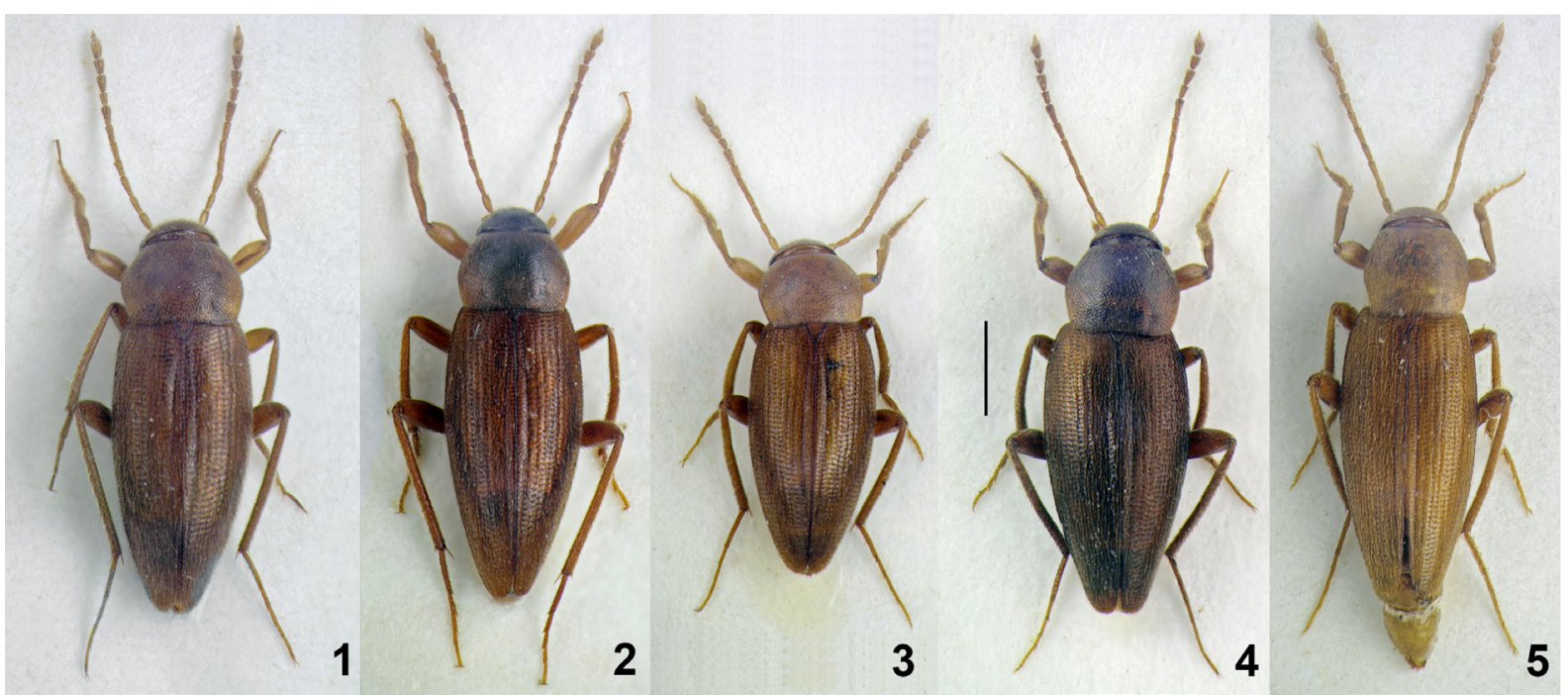

Figs 1-5. Speonemadus of the escalerai-group habitus. 1. S. algarvensis sp. nov. (Gruta do Vale Telheiro, Portugal). 2. S. angusticollis (Kraatz, 1870) (Rute, Spain). 3. S. bolivari (Jeannel, 1922) (Ardales, Spain). 4. S. breuili (Jeannel, 1922) (Motillas, Spain). 5. S. escalerai (Uhagón, 1898) (Jumilla, Spain). Scale bar $=1 \mathrm{~mm}$. 
Table 1. Mean measurements (in millimeters) of the antennomers of Speonemadus of the escaleraigroup (L) length; (W) width.

\begin{tabular}{|c|c|c|c|c|c|c|c|c|c|c|c|c|}
\hline & & $1^{\text {st }}$ & $2^{\text {nd }}$ & $3^{\text {rd }}$ & $4^{\text {th }}$ & $5^{\text {th }}$ & $6^{\text {th }}$ & $7^{\text {th }}$ & $8^{\text {th }}$ & $9^{\text {th }}$ & $10^{\text {th }}$ & $11^{\text {th }}$ \\
\hline \multicolumn{13}{|c|}{ Speonemadus algarvensis sp. nov. } \\
\hline \multirow[t]{2}{*}{ holotype $\widehat{\curvearrowright}$} & $\mathrm{L}$ & 0.189 & 0.195 & 0.212 & 0.196 & 0.194 & 0.176 & 0.196 & 0.117 & 0.166 & 0.137 & 0.221 \\
\hline & $\mathrm{W}$ & 0.065 & 0.056 & 0.056 & 0.056 & 0.056 & 0.056 & 0.075 & 0.061 & 0.088 & 0.088 & 0.090 \\
\hline \multirow[t]{2}{*}{ paratypes $\hat{\sigma}$} & $\mathrm{L}$ & 0.191 & 0.195 & 0.208 & 0.194 & 0.192 & 0.170 & 0.194 & 0.116 & 0.163 & 0.138 & 0.220 \\
\hline & $\mathrm{W}$ & 0.065 & 0.056 & 0.055 & 0.055 & 0.055 & 0.055 & 0.074 & 0.060 & 0.082 & 0.082 & 0.082 \\
\hline \multirow[t]{2}{*}{ paratypes $q$} & $\mathrm{~L}$ & 0.185 & 0.195 & 0.202 & 0.181 & 0.179 & 0.161 & 0.179 & 0.105 & 0.140 & 0.122 & 0.225 \\
\hline & W & 0.066 & 0.057 & 0.055 & 0.053 & 0.053 & 0.059 & 0.069 & 0.064 & 0.088 & 0.088 & 0.092 \\
\hline \multicolumn{13}{|c|}{ Speonemadus angusticollis (Kraatz, 1870) } \\
\hline \multirow[t]{2}{*}{$0^{\lambda}$} & $\mathrm{L}$ & 0.182 & 0.208 & 0.226 & 0.195 & 0.200 & 0.153 & 0.192 & 0.114 & 0.161 & 0.143 & 0.231 \\
\hline & $\mathrm{W}$ & 0.078 & 0.066 & 0.069 & 0.065 & 0.068 & 0.068 & 0.087 & 0.078 & 0.104 & 0.104 & 0.107 \\
\hline \multirow[t]{2}{*}{ q } & $\mathrm{L}$ & 0.177 & 0.195 & 0.205 & 0.191 & 0.195 & 0.150 & 0.190 & 0.107 & 0.159 & 0.143 & 0.231 \\
\hline & W & 0.078 & 0.068 & 0.065 & 0.065 & 0.068 & 0.065 & 0.085 & 0.073 & 0.091 & 0.091 & 0.094 \\
\hline \multicolumn{13}{|c|}{ Speonemadus breuili (Jeannel, 1922) } \\
\hline \multirow[t]{2}{*}{$0^{\lambda}$} & $\mathrm{L}$ & 0.174 & 0.177 & 0.217 & 0.186 & 0.186 & 0.170 & 0.186 & 0.117 & 0.163 & 0.140 & 0.222 \\
\hline & $\mathrm{W}$ & 0.078 & 0.059 & 0.059 & 0.056 & 0.056 & 0.060 & 0.072 & 0.061 & 0.085 & 0.088 & 0.088 \\
\hline \multirow[t]{2}{*}{ q } & $\mathrm{L}$ & 0.194 & 0.199 & 0.228 & 0.196 & 0.198 & 0.179 & 0.198 & 0.120 & 0.155 & 0.135 & 0.237 \\
\hline & $\mathrm{W}$ & 0.074 & 0.060 & 0.059 & 0.057 & 0.057 & 0.057 & 0.072 & 0.065 & 0.096 & 0.100 & 0.100 \\
\hline \multicolumn{13}{|c|}{ Speonemadus bolivari (Jeannel, 1922) } \\
\hline \multirow[t]{2}{*}{ o } & $\mathrm{L}$ & 0.182 & 0.192 & 0.228 & 0.192 & 0.203 & 0.189 & 0.205 & 0.117 & 0.156 & 0.135 & 0.231 \\
\hline & $\mathrm{W}$ & 0.066 & 0.059 & 0.055 & 0.055 & 0.060 & 0.062 & 0.073 & 0.064 & 0.088 & 0.088 & 0.094 \\
\hline \multirow[t]{2}{*}{ q } & $\mathrm{L}$ & 0.177 & 0.182 & 0.198 & 0.169 & 0.190 & 0.160 & 0.191 & 0.107 & 0.153 & 0.134 & 0.228 \\
\hline & $\mathrm{W}$ & 0.068 & 0.061 & 0.056 & 0.056 & 0.059 & 0.061 & 0.072 & 0.061 & 0.083 & 0.083 & 0.086 \\
\hline \multicolumn{13}{|c|}{ Speonemadus escalerai (Uhagón, 1898) } \\
\hline \multirow[t]{2}{*}{$\hat{0}$} & $\mathrm{~L}$ & 0.190 & 0.194 & 0.217 & 0.196 & 0.195 & 0.160 & 0.195 & 0.114 & 0.176 & 0.157 & 0.246 \\
\hline & $\mathrm{W}$ & 0.075 & 0.060 & 0.062 & 0.062 & 0.062 & 0.065 & 0.078 & 0.074 & 0.101 & 0.104 & 0.104 \\
\hline \multirow[t]{2}{*}{ q } & $\mathrm{L}$ & 0.200 & 0.207 & 0.230 & 0.208 & 0.208 & 0.169 & 0.207 & 0.120 & 0.172 & 0.156 & 0.248 \\
\hline & $\mathrm{W}$ & 0.078 & 0.072 & 0.073 & 0.074 & 0.074 & 0.077 & 0.099 & 0.082 & 0.109 & 0.111 & 0.111 \\
\hline
\end{tabular}

\section{Description}

BoDy. Length 4.03-4.90 mm (males) and 4.00-4.89 mm (females) width $1.46-1.58 \mathrm{~mm}$ (males) and 1.44-1.60 mm (females) (Figs 1, 26-27). Color reddish brown, darker in central area of head and lighter on antennae and legs. Integument evenly covered with a yellowish pubescence, thin, short and flattened, slightly raised in forehead area and clypeus. Head retractable; head sculpture composed of a tight mesh of small dots. Eyes developed with pigmented ommatidia (Fig. 27); antennae long (1.9 mm) and reaching almost one third of basal area of elytra; antennomeres (Figs 26-27, 29) slender, all clearly longer than wide; $2^{\text {th }}, 4^{\text {th }}, 5^{\text {th }}$ and $7^{\text {th }}$ antennomeres equal, 3rd slightly longer, $6^{\text {th }}$ shorter and $8^{\text {th }}$ almost twice as long as wide (Table 1); tip of antenna with sensorial organ (Fig. 29).

Pronotum (Figs 6-7). Slightly transverse, maximum width/length ratio $=1.29-1.43$ (males) and 1.281.38 (females), with maximum width at middle; almost flattened; basal impressions not observed; lateral and basal margins weakly beaded; pronotal sides regularly curved anteriorly, posteriorly almost straight and converging posteriorly; basal angles obtuse with apex almost rounded. Pronotal base narrower than base of elytra; middle area gently arched, lateral areas almost straight. Pronotum surface uniformly granulate, well defined laterally and more indistinct in disk area. 
ELYTRA. Elliptical, very elongate and convex, except along suture where they are flattened in the central area; maximum length/width ratio $=1.85-1.98$ in males and 1.95-2.02 in females; elytron apex rounded; transverse striations visible, clearly separated, shallow and perpendicular to elytral suture (Fig. 28); sutural groove present and well marked along entire elytron, sub-parallel to suture and clearly convergent. Metathoracic wings fully developed.

LEGS. Relatively long and thin; protibial keel (Fig. 16), which is high and long, elevated distally, with a well marked vertex, sharp at apex; first three protarsomeres dilated (Fig. 30) in males, first slightly narrower than apical area of protibia (tarsus/tibia ratio $=0.86$ ); mesotibia curved, metatibia straight.

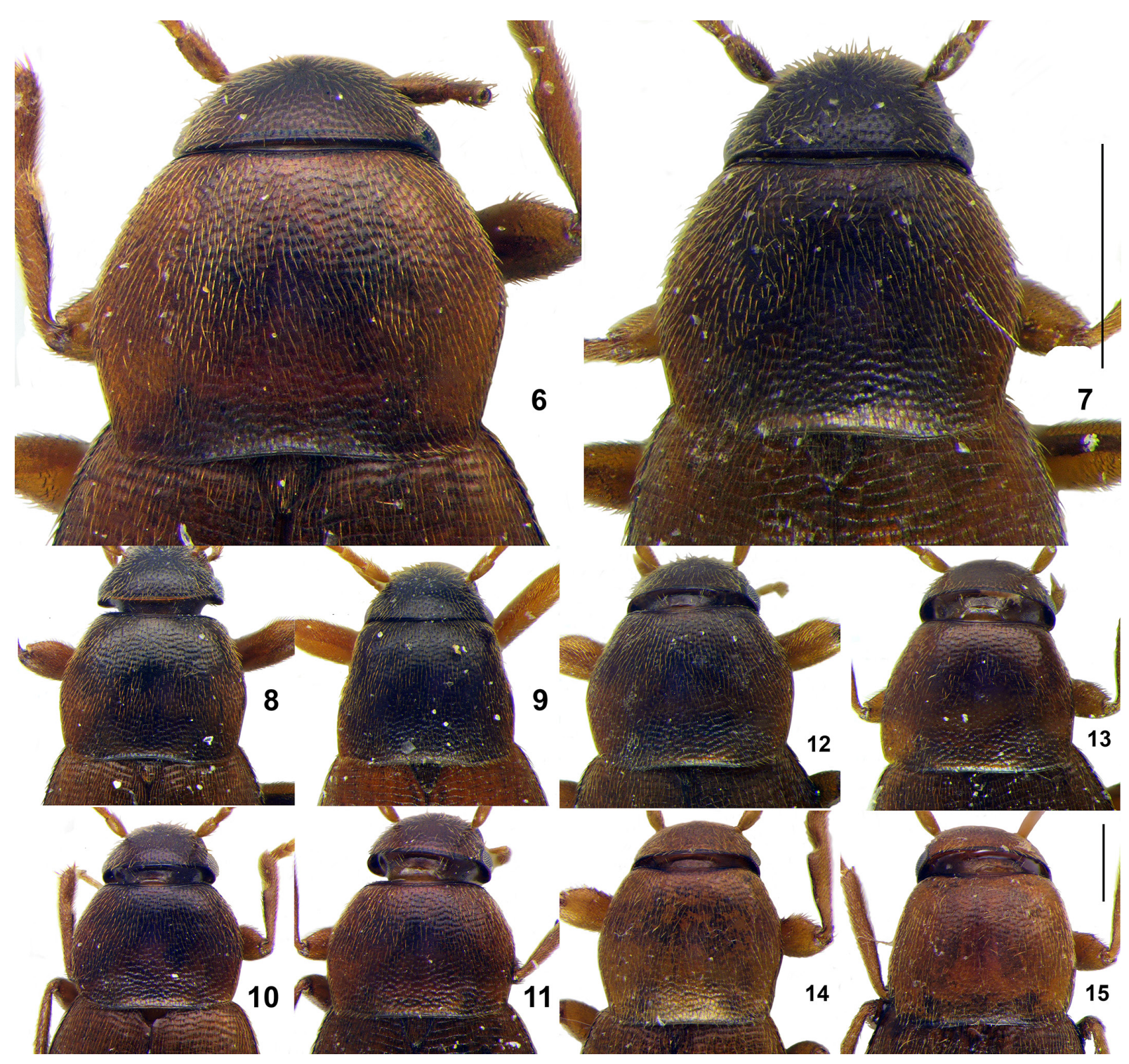

Figs 6-15. Speonemadus of the escalerai-group pronotum. 6-7. S. algarvensis sp. nov. (Gruta do Vale

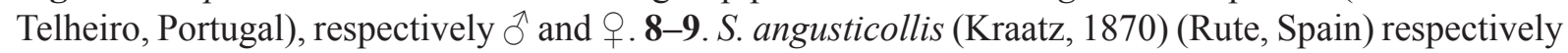
$\widehat{\delta}$ and $q$. 10-11. S. bolivari (Jeannel, 1922) (Ardales, Spain) respectively $\hat{o}$ and $q$. 12-13. S. breuili (Jeannel, 1922) (Motillas, Spain) respectively $\widehat{o}$ and $q$. 14-15. S. escalerai (Uhagón, 1898) (Jumilla, Spain) respectively 0 and $\$$. Scale bars $=1 \mathrm{~mm}$. 


\section{Male}

Some variability is observed in male paratypes (Table 1). Genital segment elongate, $1.5 \times$ longer than wide; composed of a tergum and two pleurites, all with small setae in apical area; sternum reduced to a long, narrow longitudinal piece, sharp apically. Aedeagus length $=1.2 \mathrm{~mm}$ (1.3 if parameres are included) (Fig. 21). Median lobe, lanceolate in dorsal view, with elongate and curved apex close to dorsal face; sharp apex with marked shoulders at margins; basal lamina developed, almost two times shorter than middle lobe; ventral blade of tegmen short and poorly defined. Parameres, in dorsal view, sub rectilinear, slightly curved medially on inner side, with apical areas rounded and slightly truncated on inner side; four thin setae at apex, three subequal upper setae and a larger one, close to largest setae, another seta, shorter, more robust, tooth-like and highly sclerotized. Inner sac with two long rows of spinules surrounding two long parallel rows of sclerotized teeth arranged in a zipper-shape (Figs 21, 31).

\section{Female}

Generally smaller, with a less transverse pronotum (Fig. 7) and longer elytra, but same body width. No sexual dimorphism observed in colour, pubescence, sculpture, granularity, striation, mesotibia or metatibia. Females have a slender protarsus; antennomeres proportionally thicker and elytral apex

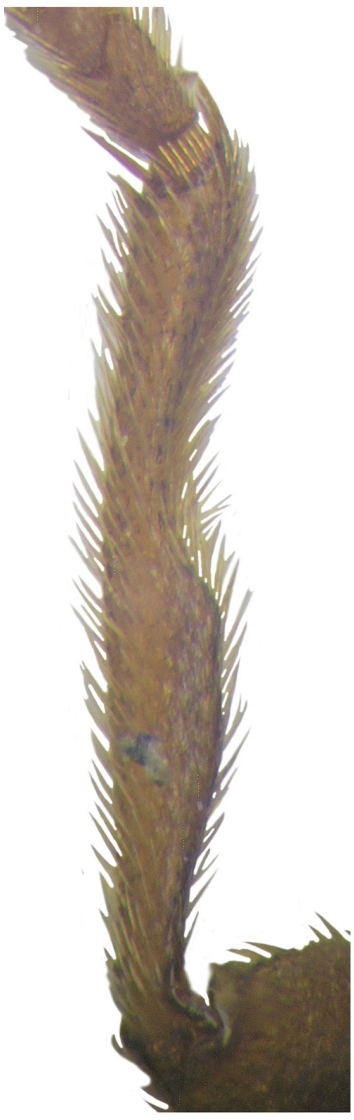

16

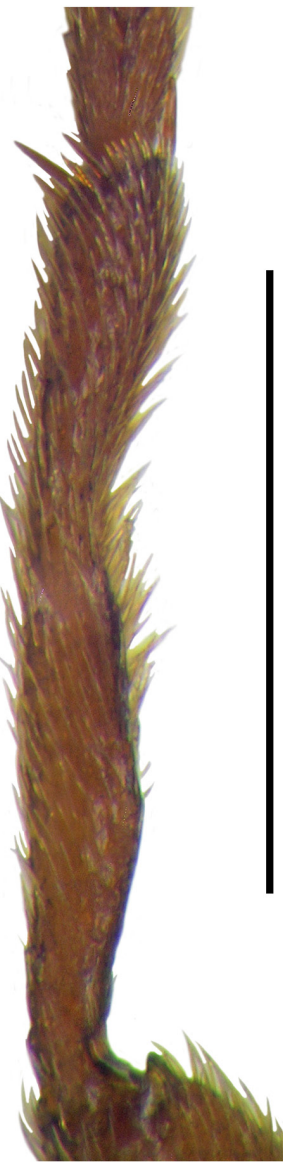

17

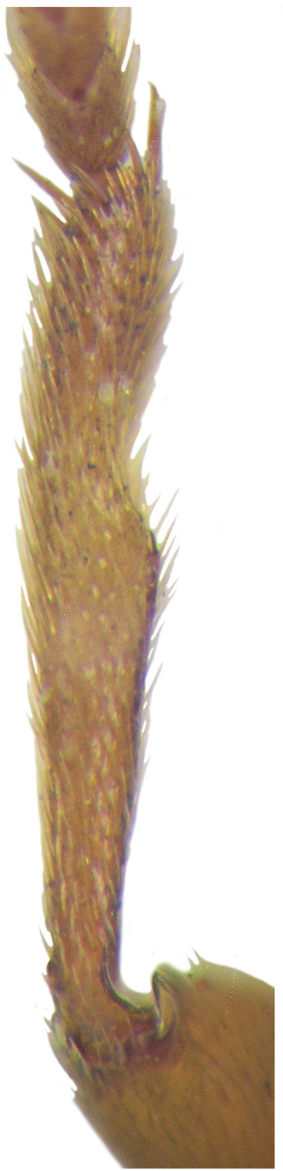

18

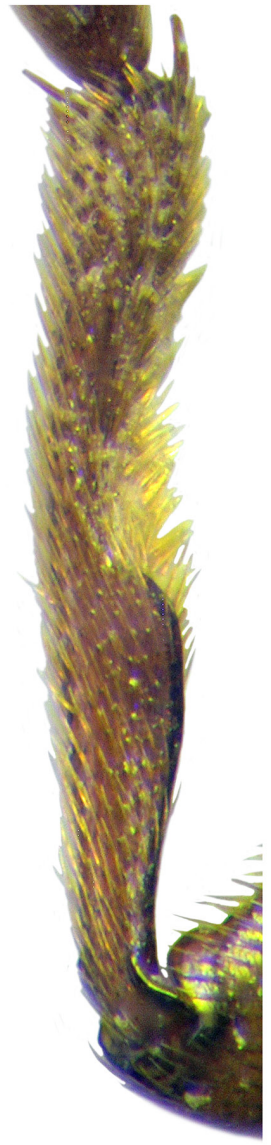

19

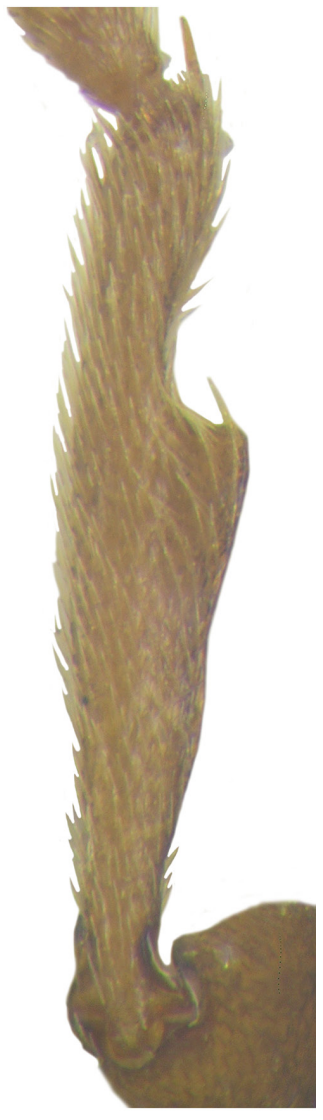

20

Figs 16-20. Speonemadus of the escalerai-group male protibia. 16. Speonemadus algarvensis sp. nov. (Gruta do Vale Telheiro, Portugal). 17. S. angusticollis (Kraatz, 1870) (Rute, Spain). 18. S. bolivari (Jeannel, 1922) (Ardales, Spain). 19. S. breuili (Jeannel, 1922) (Motillas, Spain). 20. S. escalerai (Uhagón, 1898) (Jumilla, Spain). Scale bar $=0.5 \mathrm{~mm}$. 
notched and serrate. Seventh uroventrite with a narrow slit in middle of posterior margin and $8^{\text {th }}$ uroventrite with posterior margin as a soft membranous arc, its ventral spine is short, wide and slightly sharp at apex. Ratio of first tarsus to apical part of tibia: $0.84-0.89$. Female genitalia typical of genus as described by Giachino \& Vailati (1993) and Salgado et al. (2008).

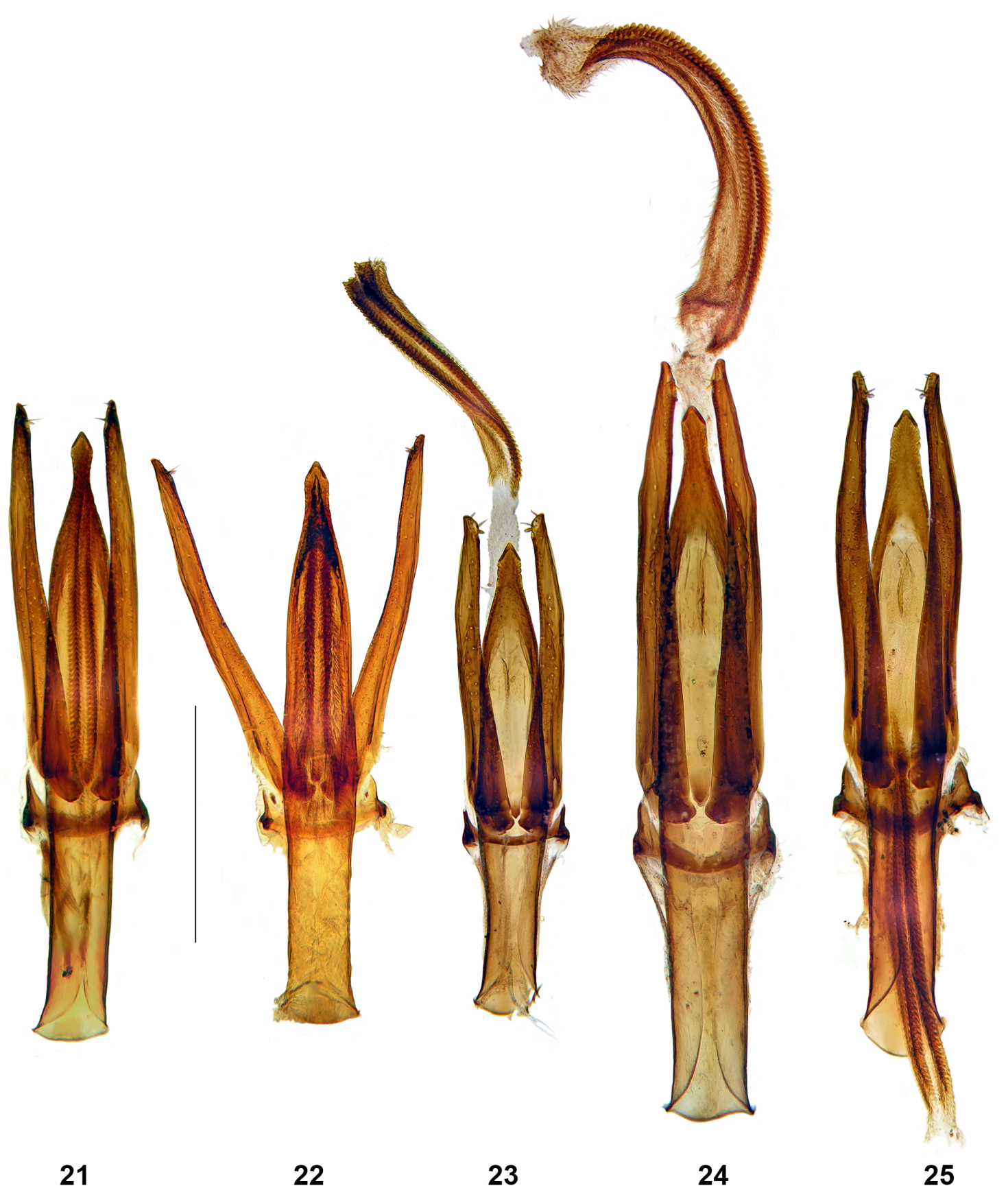

Figs 21-25. Speonemadus of the escalerai-group, aedeagus. 21. Paratype of $S$. algarvensis sp. nov. (Gruta do Vale Telheiro). 22. S. angusticollis (Kraatz, 1870) (Rute). 23. S. bolivari (Jeannel, 1922) (Ardales). 24. S. breuili (Jeannel, 1922) (Motillas).25. S. escalerai (Uhagón, 1898) (Jumilla). Scale bar $=0.5 \mathrm{~mm}$. 


\section{Affinities}

The morphological differences that separate Speonemadus algarvensis sp. nov. from all other species of the S. escalerai-group are pointed out in the key for the group.

Morphologically, the most closely related species are Speonemadus bolivari and S. breuili, which are also the closest geographically (Fig. 32). However, S. algarvensis sp. nov. can easily be distinguished from $S$. bolivari by the different shape of the male protibial keel, by the antennomeres ratio and the shape of the aedeagus, with the median lobe apically more narrow and elongate. Differences can also
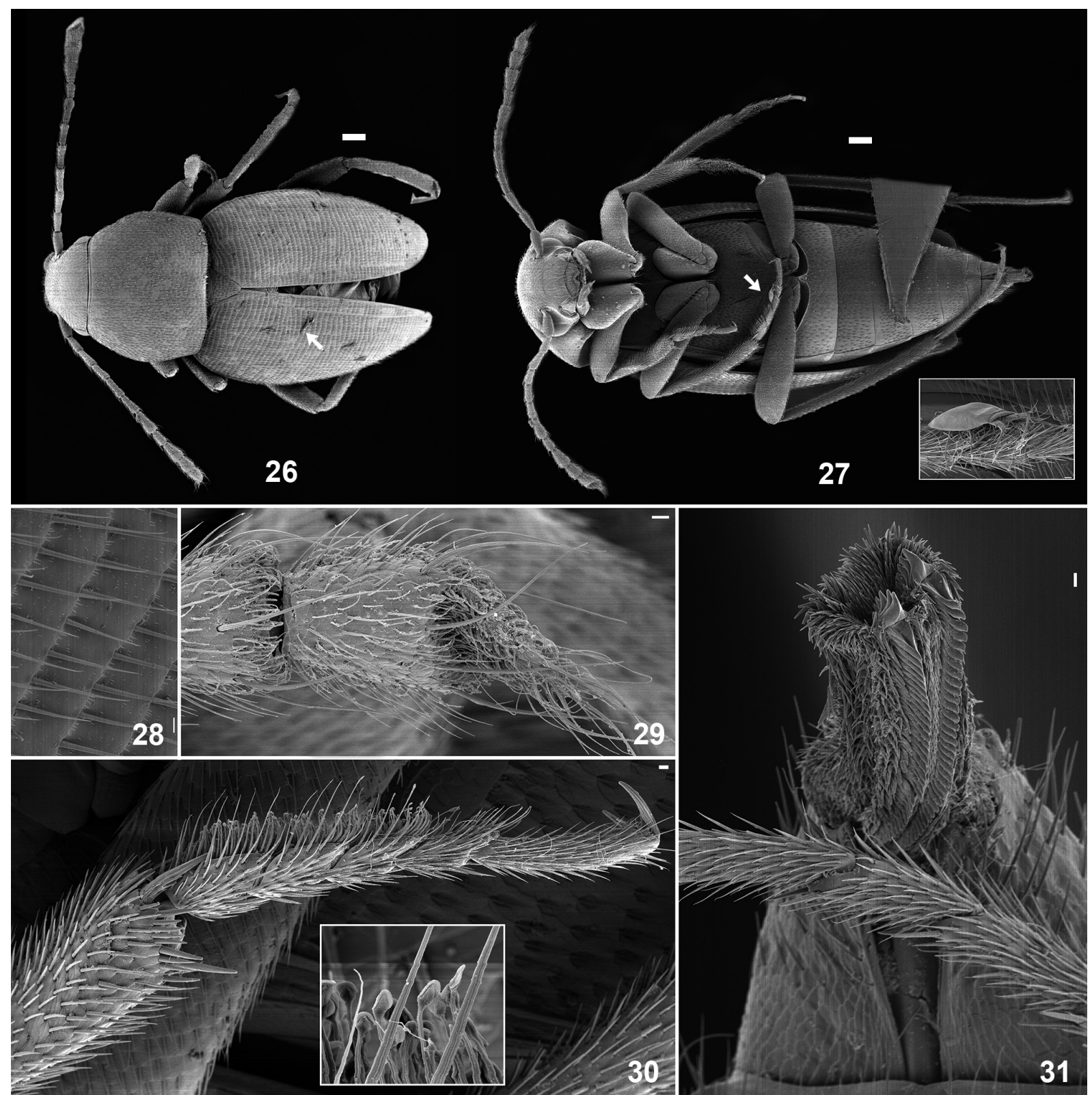

Figs 26-31. Speonemadus algarvensis sp. nov. scanning electron micrograph. 26. Dorsal view with Laboulbeniales Stichomyces conosomatis pointed out. 27. Ventral view, with detail of phoretic acari. 28. Details of elytron stria and setation. 29. Tip of the antenna. 30. Male protarsus with detail of the ventral pads of the first tarsomere. 31. Posterior dorsal view of the evaginated aedeagus. Scale bars $26-27=100 \mu \mathrm{m}, 28-31=10 \mu \mathrm{m}$. 
be observed in the females of $S$. algarvensis sp. nov., with the median posterior slit of the $7^{\text {th }}$ uroventrite slightly narrower and the apex of the ventral spine of the $8^{\text {th }}$ uroventrite less sharpened. The differences regarding $S$. breuili are much more clear in the shape of the protibial keel.

There is a strong geographic isolation between karst areas colonized by the previous three species, which have the most southern distribution of the group (Fig. 32).

The male specimen collected on 4 Jan. 1940, in the cave Igrejinha da Soídos, located in Alte, municipality of Loulé (Jeannel 1941), deposited in the Natural History Museum of Paris (MNHN), has been examined and belongs to the new species $S$. algarvensis sp. nov., it had previously been identified as $S$. angusticollis. The remnants of another specimen collected in the cave "Berrocal do Esguincho", also in the Loulé municipality, on 6 Dec. 1983 and cited by Blas $(1985,1989)$, are also included in this new species. Both aforementioned caves are included in the same karst area as the type localities of $S$. algarvensis sp. nov., where only this species of Speonemadus has consistently been collected. The specimens reported from the Algarve massif as Speonemadus angusticollis by Jeannel (1941), Blas (1985, 1989), Reboleira et al. (2010a, 2010b, 2011b, 2012a) and Reboleira (2012) should now be included in S. algarvensis sp. nov.

\section{Biology and ecology}

Despite lacking some of the typical traits of cave-adapted species, i.e., eyes, severe depigmentation and extreme body and appendages elongation, Speonemadus algarvensis sp. nov. was never found at the surface, leading us to classify it as a subterranean species. It has been sampled all year round and it has never been collected at the surface in the areas surrounding the sampled caves. The largest population was found in Vale Telheiro Cave, which matches with the general high biodiversity pattern for other groups of troglobionts in Portugal (Reboleira 2012; Reboleira et al. 2015).

Some specimens of $S$. algarvensis sp. nov. have the ectoparasitic fungus Stichomyces conosomatis Thaxt., 1901 (of the order Laboulbeniales) attached to the cuticle (Santamaria pers. com.) (Fig. 26); this represents the first record of the fungal species for the Portuguese territory. This fungus species has only been previously found in Staphylinidae beetles of the genus Sepedophilus Gistel, 1856 (Haelewaters et al. 2015), that was also found in these caves (Reboleira unpublished). The remarkable discovery of this Laboulbeniales species on a new host of the family Leiodidae is the first case of host shifting following an ecological opportunity (sensu De Kesel \& Haelewaters 2014), in the subterranean environment. Also phoretic undetermined mites were observed on some specimens (Fig. 27).

Speonemadus algarvensis sp. nov. shares its habitat with highly subterranean-adapted species such as the detritivorous woodlice Cordioniscus lusitanicus Reboleira \& Taiti, 2015 and Trogleluma machadoi (Vandel, 1946); the millipedes Acipes machadoi Enghoff \& Reboleira, 2013, A. bifilum Enghoff \& Reboleira, 2013, Boreviulisoma barrocalense Reboleira \& Enghoff, 2013 and a new species of Archipolydemus Attems, 1898; the campodeid Litocampa mendesi Sendra \& Reboleira, 2010; the nicoletiid Squamatinia algharbica Mendes \& Reboleira, 2012; and some predators: the pseudoscorpions Chthonius minutus Vachon, 1940; Titanobochica magna Zaragoza \& Reboleira, 2010 and Lusoblothrus aenigmaticus Zaragoza \& Reboleira, 2012; the spiders Harpactea stalitoides Ribera, 1993, Teloleptoneta synthetica (Machado, 1951) and Anapistula ataecina Cardoso \& Scharff, 2009, as well as a species of centipede, Lithobius Leach, 1814 (Enghoff \& Reboleira 2013; Reboleira et al. 2010a, 2010b, 2010c, 2011a, 2012a, 2012b, 2013, 2015; Reboleira \& Enghoff 2013, 2014).

\section{Distribution}

Speonemadus algarvensis sp. nov. was collected in three caves of the southernmost province of Portugal, the Algarve (Fig. 32), where it seems to be endemic to the central and eastern part of the Algarve karst massif. The species was not found in the most western part of the Algarve massif, where fieldwork 
was also conducted. The karst included in this region is also know as "Barrocal" and is the richest area for subterranean-adapted fauna of the country (Reboleira 2012; Reboleira et al. 2011a, 2013, 2015; Reboleira \& Enghoff 2013, 2014).

\section{Speonemadus angusticollis (Kraatz, 1870)}

Choleva angusticollis Kraatz, 1870: 98.

Catops angusticollis - Marseul 1884: 69.

Anemadus angusticollis - Reitter 1885: 60.

Speonemadus angusticollis - Jeannel 1936: 220.

\section{Type locality}

"Cordova" (Kraatz 1870).

\section{Material examined}

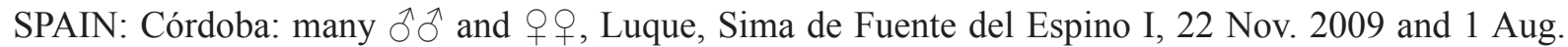
2010, GES-Priego leg. (CFL, CPB, CJMS, CZULE); 1 ð, 2 오, Sima Fuente de Alhama, 3 Apr. 2010, GES-Priego leg. (CFL); many $\widehat{\partial} \widehat{\jmath}$ and $q$ 우, Priego de Córdoba, Cueva de la Solana, 6 Dec. 2009 and 7 Feb. 2010, GES-Priego leg. (CFL, CPB, CJMS). — Guadalajara: 1 o, 1 q, Tamajón, Cueva de Remigín, 10 Apr. 1994, Carabajal leg. (CZULE). - Huelva: 6 우, Fuenteheridos, Cueva del Guerrero, 23 Mar. 2013 CDP leg. (CPB, CJMS); 3 đo 0 , 4 우, same locality, 5 Jun. 2013, CDP leg. (CPB, CJMS). - Jaén: 11 §ð, 28 우, Hornos, Cueva de la Murcielaguina, 15 Nov. 2009, GEV leg. (CFL,

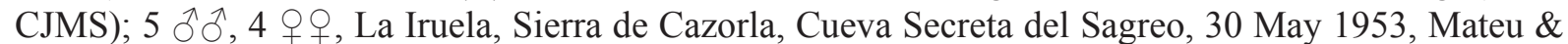
Cobos leg. (CMCN); 4 $\widehat{\partial}, 2$ q $ᄋ$, Sierra de Cazorla, Cueva del Nacimiento de Guadalquivir, 8 Aug.

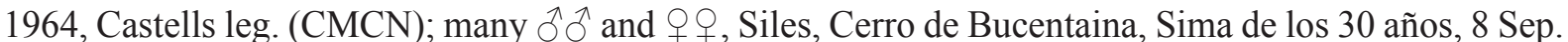

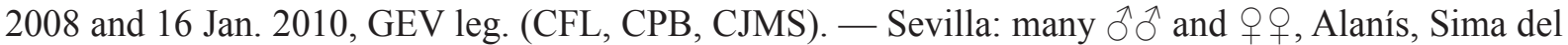
Paro, 23 Jan. 2013, CDP leg. (CFL, CPB, CJMS).

PORTUGAL: 1 đ̂, Alandroal, Estremoz-Cano massif, Algar de Santo António, 30 Mar. 2009, A.S. Reboleira leg. (SR).

\section{Previous records}

SPAIN: Albacete: Riópar, Cueva del Farallón (Blas 1989; Giachino \& Vailati 1993; Fresneda et al. 2007); Riópar, Sierra de Segura, Cueva de la Umbría de Santiago (Blas 1989; Pérez 2014). - Ávila: Villarejo del Valle (Uhagón 1890, 1898; Jeannel 1922; Blas 1977, 1979, 1989; Giachino \& Vailati 1993).- - Badajoz (Uhagón 1890, 1898; Jeannel 1922, 1936; Fuente, 1925; Blas 1979): Cabeza la Vaca, Los Cortinales (Sáez \& Blanco 2010); Calera de León, Monasterio de Tentudía (Sáez \& Blanco 2010). — Cáceres (Fuente 1925): Navalmoral de la Mata (Uhagón 1898; Blas 1977, 1979). — Ciudad Real: Horcajo de los Montes, P.N. de Cabañeros, Pinar de las Llanas (Fresneda et al. 2007); Pozuelo de Calatrava (Uhagón 1898; Blas 1989; Giachino \& Vailati 1993); Retuerta del Bullaque, P.N. de Cabañeros, Los Palillos (Fresneda et al. 2007). - Córdoba: Cabra, Cueva-Mina de Jarcas (Fresneda et al. 2007; Pérez 2015); Cabra, La Nava (Fresneda et al. 2007); Cabra, Cueva Ca-2 (Blas 1989; Tinaut 1998); Córdoba (Kraatz 1870; Uhagón 1890; Jeannel 1922, 1936; Blas 1979; Giachino \& Vailati 1993); Luque, Abuchite, L-14 (Fresneda et al. 2007, 2011); Priego de Córdoba, Cueva de los Mármoles (Fresneda et al. 2007, 2011; Pérez 2015); Priego de Córdoba, Castillo, in archaeological excavations under the castle (Fresneda et al. 2007); Rute, Cueva la Negra (Fresneda et al. 2007); Zagrilla, Manantial (Fresneda et al. 2007); Zuheros, Cueva de los Murciélagos (Fresneda et al. 2007; Pérez 2015). - Huelva: Aracena, Gruta de las Maravillas (Blas 1979, 1989). - Jaén: Hornos, Cueva de la Murcielaguina (Fresneda et al. 2007); La Iruela, Sierra de Cazorla, Cueva Secreta del Sagreo (Mateu 1953; Ribera 1970; Blas, 1976, 
1977, 1979, 1989; Giachino \& Vailati 1993; Tinaut 1998, Pérez \& Tinaut 2005; Pérez \& Pérez 2006; Pérez et al. 2013); Peal de Becerro, Cueva del Arroyo de la Rambla, PB-4, (Tinaut 1998; Fresneda et al. 2007); Santa Elena (Blas 1977, 1979, 1989); Sierra de Cazorla, Cueva del Nacimiento de Guadalquivir (Ribera 1970; Blas 1976, 1977, 1989; Tinaut 1998; Pérez \& Tinaut 2005; Pérez 2015); Siles, Cerro de Bucentaina, Sima de los 30 años (Fresneda et al. 2007; Ribera et al. 2010). — Madrid: Escorial (Uhagón 1890, 1898; Jeannel 1922, 1936; Blas 1977, 1979, 1989); Sierra de Guadarrama, Navacerrada (Uhagón 1890, 1898; Jeannel 1922, 1936; Fuente 1925); Robledo de Chavela (Blas 1989). — Sevilla: Alanís, Sima los Coscojales (CFL) (Fresneda et al. 2007); Almadén de la Plata, Cueva de los Covachos (Pérez 2015).

\section{Redescription}

BoDy. Length 4.0-4.6 mm (males) and 4.1-4.6 mm (females), body width 1.3-1.4 mm (males) and 1.4$1.6 \mathrm{~mm}$ (females). Body shape elongate and very slim (Fig. 2). Integument color light brown to darker brown, the legs, antennae and palpi of similar color; pubescence arranged uniformly, golden, moderately long and adpressed, only erected on the clypeus. Head retractable, with well-developed eyes. Antennae quite long, greyish in color, reaching the basal $1 / 5$ part of the body; all antennomeres longer than wide, $3^{\text {rd }}$ antennomere longer than $2^{\text {nd }}$ antennomere, $4^{\text {th }}$ and $6^{\text {th }}$ antennomeres shorter than $5^{\text {th }}$ one, and $8^{\text {th }}$ almost $1.5 \times$ longer than wide (Table 1$)$.

Pronotum . Slightly transverse with surface slightly punctured (Figs 8-9), maximum width/length ratio = 1.20-1.32 (males) and 1.18-1.25 (females), with maximum width in the middle third and the lateral edges regularly arcuate, converging towards the base; posterior angles obtuse and slightly rounded at apex. Pronotal base sinuate and narrower than elytral base.

Elytra. Elliptical and very elongated, maximum length/width ratio $=2.04-2.19$ (males) and 1.97$2.11 \mathrm{~mm}$ (females); apex of each elytron rounded; elytral disk slightly convex and flattened in the middle. Elytral sculpture formed by very strong sutural striae and transverse strias with regular arrangement, sunken, well marked and perpendicular to the suture.

\section{Male}

The structure of genital segment corresponds to the typical pattern of the genus, formed by an urotergite with the apex in sharp bow, two uropleurites with apically narrow, sharp, slightly outwardly and short shaped handle ventrite. Aedeagus robust and long, between 1.2 and $1.3 \mathrm{~mm}$ (Fig. 22); basal lamina almost $2 \times$ shorter than middle lobe; ventral blade of tegmen short and poorly defined. Median lobe in dorsal view, similar to other species of the group, although it has the triangular apex with less protruding edge and narrower at its distal third part. Parameres robust and wide with a marked hump on the outside of distal and the apical area is beveled with a blunt tip, in this area four setae are inserted, of which three are short and thin, and the fourth is longer with a small tooth, coarse and finely sclerotized. Inner sac showing two longitudinal chains of small sclerotized pieces, surrounded by a longer structure formed by numerous fine spines that are joined at the apex, but not tooth-shaped. Legs long with a peculiar structure of the keel protibial (Fig. 17) which is long, slightly elevated, with a straight area, and fuzzy projections; in addition, the first three protarsomeres are dilated, although first protarsomere is narrower than anterior area of protibia; mesotibia arched and metatibia straight.

\section{Female}

The most significant external differences are observed on the antennae, pronotum, elytra, protibia and protarsomeres. Antennae very similar to those observed in males (Table 1); the $2^{\text {nd }}$ antennomere equal to the $5^{\text {th }}$ one, and the $8^{\text {th }}$ almost $1.5 \times$ longer than wide. Pronotum slightly transverse and clearly narrower than in males (Fig. 9), its sides almost straight and divergent on the posterior part; the maximum width is near the base and bell-like in form; posterior angles are almost straight with rounded angles; pronotal 
base is almost as wide as base of elytra. Elytra are elliptical and elongated and proportionally slightly shorter than in males. Apex of elytra is notched and toothed. Protibiae lacking keel and protarsi slender. $7^{\text {th }}$ and $8^{\text {th }}$ uroventrites and genital segment typical of the genus (see Giachino \& Vailati 1993).

\section{Variability}

The most significant variation was observed in the samples from the two caves of Huelva (Gruta de la Maravillas and Cueva del Guerrero), specimens from both caves show intermediate characteristics between $S$. angusticollis and S. breuili, with the protibial keel more close to the first one and female pronotum most similar to the second species. Systematic position of the specimens collected from these two caves will be solved only by further study of specimens from caves near the Sierra de Aracena.

\section{Biology and ecology}

This species is found in a forest environment, in leaf litter or under stones. In arid climates it tends to colonize the subterranean ecosystem, being frequently found in caves, as in Spanish Andalusia and now also in the Portuguese region of Alentejo. In less dry regions it is found to be more associated with the soil ecosystem (Blas 1977). It has been also been reported (Giachino \& Vailati 1993) from the Superficial Subterranean Habitat (sensu Giachino \& Vailati 2010).

\section{Distribution}

Described from Spanish Córdoba (Kraatz 1870), this is an Iberian endemic with a scattered distribution in the central area of the peninsula, being more common in its southern and western parts. It is known from the Spanish provinces of Albacete, Ávila, Badajoz, Cáceres, Ciudad Real, Córdoba, Huelva, Jaén, Madrid and Sevilla and now also from southeastern Portugal (Fig. 32). The present finding in a cave of Alandroal, in the Alentejo province, is the first confirmed record of this species for the Portuguese territory as previous records for Portugal (Jeannel 1941, Blas 1985, 1989, Reboleira 2012, Reboleira et al. 2010a, 2010b, 2011a, 2012a) refer to S. algarvensis sp. nov.

Speonemadus breuili (Jeannel, 1922)

Anemadus (Speonemadus) breuili Jeannel, 1922: 60.

Anemadus (Speonemadus) verneri - Jeannel 1922: 61.

Anemadus (Speonemadus) angusticollis breuili - Jeannel 1936: 221.

Anemadus (Speonemadus) angusticollis verneri - Jeannel 1936: 221.

\section{Type locality}

“Cueva de las Motillas, Jerez de la Frontera, provincia de Cádiz” (Jeannel 1922).

\section{Material examined}

SPAIN: Cádiz: $3 \widehat{\jmath}$ đ̂, 2 우, Villaluenga del Rosario, Cueva Aljíbez (= Cueva del Aljíbe, Jul. 1970, Ribera \& Viñas leg. (CMCN). - Málaga: many ${ }^{\lambda} \widehat{\jmath}$ and + + , , Cortés de la Frontera, Cueva del Berrueco, 12 Sep. 2009 and 6 Jun. 2010, GIEX leg. (CFL, CPB, CJMS, CZULE); 15 ふ઼, 9 우 Cortés de la

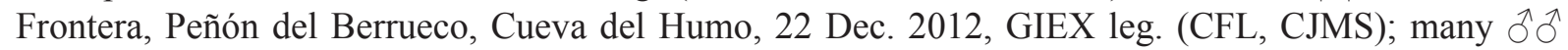
and $q+$, Cortés de la Frontera, Complejo Motillas, Cueva Motilla fósil, 13 Sep. 2009 and 8 Nov. 2009,

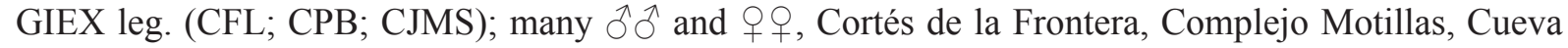
Motilla Parralejo, 13 Sep. 2009, 8 Nov. 2009 and 5 Jun. 2010, GIEX leg. (CFL, CPB, CJMS, CZULE); 1 ㄱ, 2 우우, Montejaque, El Pozuelo, Cueva Sima Nueva, 29 Mar. 1986, Escolà leg. (CMCN). 


\section{Previous records}

SPAIN: Cádiz, Algeciras (Giachino \& Vailati 1993); Algeciras, Los Barrios (Blas 1989; Giachino \& Vailati 1993); Villaluenga del Rosario (Giachino \& Vailati 1993); Villaluenga del Rosario, Cueva Aljíbez (=Cueva del Aljibe) (Blas 1976, 1977, 1979; Tinaut 1998; Pérez 2015); Vilalluenga del Rosario, Sima Aljibe nº 2, (Ribera 1970). - Málaga, Cortés de la Frontera, Cueva del Berrueco (Jeannel 1922, 1936; Ribera 1970; Blas 1976, 1979; Giachino \& Vailati 1993; Tinaut 1998); Cortés de la Frontera, Cueva de las Motillas (Ribera 1970; Blas 1977, 1979, 1989; Giachino \& Vailati 1993; Tinaut 1998; Fresneda et al. 2007); Montejaque, El Pozuelo, Cueva Sima Nueva (Blas 1989); Montejaque, El Pozuelo, Cueva del Requejo (Blas 1979, 1989; Tinaut 1998; Pérez 2015); Montejaque, El Pozuelo, Cueva Sivieja (Blas 1989; Tinaut 1998; Pérez 2015).

\section{Redescription}

Body. Length 4.0-4.5 (males) and 3.9-4.7 mm (females), body width 1.4-1.5 (males) and 1.5-1.7 mm (females) (Fig. 4). Body color, pubescence and punctuation similar to that observed in S. angusticollis.

ANTENNAE. Reaching the basal $4^{\text {th }}$ part of elytra; the antennomeres $1^{\text {st }}$ and $2^{\text {nd }}$ are almost equal in length, also equal in length are the $4^{\text {th }}, 5^{\text {th }}$ and $7^{\text {th }}$ ones being the $3^{\text {rd }}$ ones clearly longer than the $2^{\text {nd }}$ one and the $8^{\text {th }}$ nearly twice as long as wide (Table 1 ).

Pronotum. Slightly transverse, maximum width at middle third part; the angles converge, smoothly from the middle area to the base in a straight line; posterior angles obtuse and rounded at vertex; sculpture and granularity well defined (Fig. 12).

ELYTRA. Elliptical and elongated, maximum length/width ratio $=1.92-2.10$ (males) and 1.86-2.04 mm (females), with overall shape of the species group and sculpture of "C" type (sensu Giachino \& Vailati 1993).

Male (Fig. 24)

Features of the genital segment and aedeagus are similar to those described for S. angusticollis.

\section{Female}

The antennae are similar to those of the male, but the antennomeres are more transverse; $2^{\text {nd }}, 4^{\text {th }}, 5^{\text {th }}$ and $7^{\text {th }}$ antennomeres having similar length (Table 1). Pronotum less elongated; the overall shape and the ratio of width/length ratio similar to that described for males (Fig. 13). Elytra elliptical and elongated with apical parts notched and serrated. $7^{\text {th }}$ and $8^{\text {th }}$ uroventrites, and genitalia typical of the species group.

\section{Remarks}

Speonemadus breuili is re-established as a valid species due to the clear morphological characters that differentiate it from S. angusticollis, which was synonymized by Blas (1989). This classification was subsequently followed by several authors (Giachino \& Vailati 1993; Perreau 2000; Salgado et al. 2008). The main character used to re-evaluate its specific status is the shape of the male protibial keel, which is shorter and with a more rounded ridge, but also because in S. breuili the $8^{\text {th }}$ antennomere is less transverse, the elytra are proportionally shorter, and the female pronotum is more hexagonal and clearly transverse. In addition, Speonemadus verneri is established as a synonym of $S$. breuili and not of S. angusticollis (Blas 1989), due to the absence of relevant differences compared to $S$. breuili.

Apart from the morphological differences pointed out, there is an obvious geographical isolation. Speonemadus breuili colonizes the southernmost caves in Spanish Andalusia, the provinces of Cadiz and Málaga, away from the distribution area of S. angusticollis. 


\section{Biology and Ecology}

Speonemadus breuili is commonly found in the subterranean ecosystem, as are the other species of the group. Inside the caves, it is found mainly in parts rich in organic matter and with a high humidity.

\section{Distribution}

Speonemadus breuili is the southernmost species of the escalerai-group in the Iberian Peninsula, found in the provinces of Cadiz and Málaga. The limit of its northern distribution is established by the mountain ridge of Ronda. It is distributed in the Sierra de Grazalema and related foothills, while the distribution of $S$. bolivari is linked to the Sierra de Nieves and its foothills. Both mountain ranges are separated geographically by a wide valley of sedimentary material (Fig. 32).

Speonemadus bolivari (Jeannel, 1922)

Anemadus (Speonemadus) bolivari Jeannel, 1922: 48, 59.

Speonemadus bolivari - Jeannel 1936: 220.

\section{Type locality}

"Cueva de la Doña Trinidad, term. mun. de Ardales, partido de Campillos, provincia de Málaga" (Jeannel 1922).

\section{Material examined}

SPAIN: Granada: 10 $\widehat{\partial} \hat{0}, 10$ 우, Íllora, Sierra de Parapanda, Cerro de la Mesa, Sima San Rafael, 9 Mar. 2013, GEG leg. (CPB; CJMS); many $\widehat{\jmath} \delta$ and $q$ + , Piñar, Cueva de Pagarrecio, 15 Dec. 2012 and 10 Mar. 2013, GEG leg. (CFL, CPB, CJMS, CZULE). — Málaga: 1 đ̊, 1 +, Ardales, Cueva de Ardales,

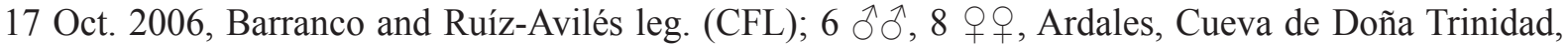
17 Jan. 2007, Barranco and Ruíz-Avilés leg. (CPB, CJMS); many ${ }^{\lambda} \delta$ and $q+q$, Antequera, Cueva de los Higuerones IX, karst en yesos de Gobantes-Meliones, 28 Nov. 2009 and 30 Sep. 2010, GES-SEM leg. (CFL, CPB, CJMS); 4 ડ̄o , Benaoján, Sierra de Grazalema, Cueva de la Pileta, 17 Jan. 2007, Barranco leg. (CJMS); 1 O̊, Benalmádena, Cueva de los Botijos, 31 Jul. 1977, Abad leg. (CFL); 1 \&, Tolox, Sima Raja Helada, 28 Sep. 2009; 1 $\widehat{\delta}$ and 3 우, same locality, 25 Jul. 2008, GES-SEM leg. (CPB, CJMS).

\section{Previous records}

SPAIN: Málaga: Ardales, Cueva de Doña Trinidad (Jeannel 1922, 1936; Coiffait 1954; Ribera 1970; Blas 1976, 1977, 1979, 1989; Tinaut 1998; Giachino \& Vailati 1993; Barranco 2005; Fresneda et al. 2007; Pérez 2015); Antequera; Complejo del Romeral, (Fresneda 2008, Fresneda et al. 2011); Antequera, karst en yesos de Gobantes-Meliones, Cueva del Yeso (Fresneda 2008); Benaoján, Cueva de la Pileta (Blas 1989; Giachino \& Vailati 1993; Tinaut 1998; Fresneda et al. 2007); 1 + Ronda, Sima del Hoyo Jaralón, 16 May 1922 (Blas 1979, 1989; Giachino \& Vailati 1993; Tinaut 1998; Pérez 2015); Ronda, Sierra de las Nieves, Cueva del Rejete (Coiffait 1954; Ribera 1970; Blas 1976, 1977, 1979, 1989; Giachino \& Vailati 1993; Tinaut 1998; Pérez 2015); Ronda, Sumidero del Rejete (Blas 1976, 1989); Sierra de Ronda, Sima E Las Palomas (Blas 1979, 1989; Tinaut 1998). — Granada: "Loja, 4.1909, Exp. del Museo, coll. Muséum d'Histoire Naturelle, Paris” (MNHN) (Szymczakowski 1970).

\section{Redescription}

Body. Length 3.9-4.5 (males) and 4.1-4.5 mm (females), body width 1.3-1.4 mm (males) and 1.4$1.6 \mathrm{~mm}$ (females). Body shape very long and slender (Fig. 3). The Integument light brown, slightly darker on the head. Pubescence fairly long, golden and slightly raised. Head retractable with welldeveloped eyes; pubescence adpressed on its forehead and slightly raised on the clypeus. 
AnTENNAE. Long, slender, light brown and extended beyond the basal fourth of elytra; $3^{\text {rd }}$ antennomere slightly longer than the $2^{\text {nd }}$ one; $6^{\text {th }}$ one shorter than $4^{\text {th }}$ and $5^{\text {th }}$ ones, and the latter one as long as the $7^{\text {th }}$ one; $8^{\text {th }}$ almost $1.5 \times$ longer than wide (Table 1 ).

Pronotum. Slightly transverse, maximum width $/$ length ratio $=1.23-1.39$ (males) and $1.28-1.36 \mathrm{~mm}$ (females); with a maximum width towards the middle; basal impressions are not hardly noticeable; side edges regularly arched forward, almost straight and towards the posterior angles that are obtuse and rounded in the vertex (Fig. 10); pronotal base as wide as elytral base; sculpture has a coarse granularity with obvious microsculpture.

ELYTRA. Elliptical and elongated with rounded apical areas, maximum length $/$ width ratio $=1.95-$ 2.04 (males) and 1.88-1.98 mm (females); elytral disc is slightly convex, and briefly depressed along suture at half of basal part. Sutural stria and discal striae well marked.

\section{Male}

Genital segment very similar to the other species of the escalarai-group and following the model described for Speonemadus algarvensis sp. nov. Aedeagus long, $1.1 \mathrm{~mm}$; basal lamina of median lobe well developed and more than half of the median lobe length; ventral blade of tegmen short, inconsistent and forms the widest part of the aedeagus. In dorsal view, median lobe is bottle-shaped, with converging sides towards the base and narrowed distally; apex tapers and ends in a triangular tip with the sides slightly beaded dorsally (Fig. 23). Parameres robust, only curved forwards; apical parts obliquely truncated on the inner side, where four setae are inserted, three thin, subequal, and a larger one, as well as a thick and well sclerotized small tooth. Inner sac with two longitudinal chains formed by small sclerotized parts and surrounded by two longer chains of fine and sharp spines that come together in the apical region, but do not form a typical sclerotized tooth as in other species.

LeGs. Quite long; the protibial keel is elevated in the anterior middle third, showing a single, well marked, projection angle (Fig. 18); first three protarsomeres dilated, being the first almost as wide as the apical tip of the protibia; mesotibia strongly arched and metatibia straight.

\section{Female}

Antennae slightly shorter and more robust than in the male, reaching third basal part of elytra; $2^{\text {nd }}$ antennomere is slightly longer than the $3^{\text {rd }}$ one and $5^{\text {th }}$ one longer than $4^{\text {th }}$ and $6^{\text {th }}$ ones; the $8^{\text {th }}$ being clearly longer than wide (Table 1). Pronotum less transverse, but appears longer (Fig. 11). Elytra elliptical and elongated with notched and serrated apical areas. The sexual dimorphism is clear for all species of this group, as well as the structures in uroventrites $7^{\text {th }}$ and $8^{\text {th }}$, and spermatheca model.

\section{Biology and ecology}

Subterranean species, found in deep areas of scattered caves, under stones or on calcite mantles. Groups of adults and larvae have been found in small accumulations of organic matter, such as bat guano.

\section{Distribution}

Speonemadus bolivari is endemic to several karst caves located in a narrow strip within the province of Málaga, between the Serrania de Ronda, at the western limit, and the karst areas at its border with the province of Granada, such as the Romeral complex, at its eastern limit. The three distribution records for the Granada province are located to the north and east of the massif of the Sierra Nevada (Fig. 32).

\section{Speonemadus escalerai (Uhagón, 1898)}

Anemadus escalerae Uhagón, 1898: 118. 
Anemadus (Speonemadus) escalerae - Jeannel 1922: 58.

Speonemadus escalerai zariquieyi - Jeannel 1936: 221.

Speonemadus escalerai - Jeannel 1936: 221.

The specific epithet proposed by Uhagón (1898) in the description was escalerae. However, the spelling escalerai has mostly been used in the entomological literature; since its use is prevalent, attributed to the original author, according to the ICZN (2016: Article 33.3.1), we propose to continue to use escalerai.

\section{Type locality}

"Cuevas de la Zarza, del Seguret y del Encomat, cerca de Bocairente" (Uhagón 1898).

\section{Material examined}

SPAIN: Alicante: $3 \hat{\jmath} \hat{\jmath}, 2$ q $q$, Xixona, Cova-Avenc de Barratxina, 25 May 1976, Comas and Escolà

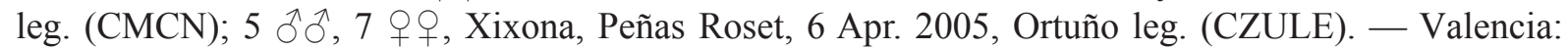
$3 \partial^{\lambda}, 1$ ㅇ, Bocairent, Cova Sarsa, Zaragoza leg. (CMCN); 1 ․, Enguera, Sima de la Carrasquilla, 8 Mar. 1993, Montagud leg. (CZULE).

\section{Previous records}

SPAIN: Alicante: Albaida, Castalla, Cova Melxor (Blas 1977, 1979, 1989; Zaragoza \& Sendra 1988); Banyeres, Avenc de Vinalogó (Blas 1977, 1979, 1989; Zaragoza \& Sendra 1988); Onil, Cova-Avenc de la Foieta (= Cova de la Foieta, Cueva-Sima de la Foieta) (Jeannel 1936; Blas 1979); Onil, Cova de Galiano (Zaragoza \& Sendra 1988); Onil, Cova de Garbina (Jeannel 1936; Blas 1979); Onil, Cova Porrasses (Blas 1977, 1979, 1989; Zaragoza \& Sendra 1988); Xixona, Cova-Avenc de Barratxina (Blas 1977, 1979, 1989; Zaragoza \& Sendra 1988). MuRcia, Jumilla, Sierra del Carche, MSS (Blas 1989; Giachino \& Vailati 1993; Fresneda et al. 2007); Jumilla, Cueva Los Cachorros (Blas 1989); Jumilla, Sima los Cachorros, (Fresneda et al. 2007); Jumilla, Cueva Los Tiestos (Blas 1989). — Valencia: Bocairent (Blas 1979); Bocairent, Cueva del Encomat (Uhagón 1898; Jeannel 1922, 1936; Blas 1977, 1979); Bocairent, Cueva del Seguret (Uhagón 1898; Jeannel 1922, 1936; Blas 1977, 1979, 1989; Giachino \& Vailati 1993); Bocairent, Cueva de la Zarza (Uhagón 1898; Jeannel 1922, 1936; Blas 1977; 1979, 1989; Giachino \& Vailati 1993); Bocairent, Cova Sarsa, (Blas 1979, 1989).

\section{Redescription}

Body. Length 4.5-5.0 mm (males) and 4.4-4.9 mm (females); body width 1.3-1.6 mm (males) and 1.3-1.5 mm (females). Body shape long and slender (Fig. 5). Integument reddish brown; pubescence fairly long, golden and lying. Head structure similar to other species of the group.

AnTENNAE. Long and slender, when oriented back reaching sixth basal part of elytra; $3^{\text {rd }}$ antennomere slightly longer than $2^{\text {nd }}$ one; $2^{\text {nd }}, 4^{\text {th }}, 5^{\text {th }}$ and $7^{\text {th }}$ ones are similar in length and longer than the $6^{\text {th }}$ one; $8^{\text {th }}$ is $1.5 \times$ longer than wide (Table 1 ).

Pronotum. Slightly transverse, maximum width / length ratio $=1.19-1.30$ (males) and 1.131.20 (females); hexagonal in dorsal view, with maximum width in middle; sides arcuate and almost linear converging towards the base (Fig. 14); posterior angles obtuse with rounded apex. Base of pronotum almost as wide as base of elytra, gently curved sideways and finely beaded. Median granularity sculpture.

ELYTRA. Elliptical and very elongated, maximum length/width ratio $=2.06-2.18$ (males) and 1.962.06 (female), with rounded apical areas; elytral disc slightly convex and depressed along suture in its half basal part; elytral suture well-marked with thin transverse striae, distant and perpendicular to suture. 


\section{Male}

Aedeagus and structures of inner sac are similar to those described for S. bolivari, although larger in shape, length 1.4-1.5 $\mathrm{mm}$ (measured to the apex of the parameres); in dorsal view very similar to all the species of the group but in close slimmer apical area (Fig. 25). Parameres also similar to S. bolivari, but with more pronounced steeper area of outer margin in third distal part.

Genital SEgment structure. Similar to that described for Speonemadus algarvensis sp. nov.

LEGs. Relatively long and slender; protibia widened in apical area and with a long keel running through the two basal thirds of the margin, showing two sharp protrusions, separated by a slight depression, anterior is sharp and much higher and the second is fuzzy (Fig. 20); first three protarsomeres are dilated, the first being slightly narrower than the anterior tip of protibia; mesotibiae arched and metatibiae slightly arched.

\section{Female}

Antennae long, reaching the basal third of elytra, with antennomeres generally slightly longer and transverse (Table 1). Pronotum not so transverse; in dorsal view subrectangular, with side margins almost straight before maximum width; which is situated towards the third part of basal area (Fig. 15). Elytra elliptical and elongate, with notched and serrated apical areas. Sexual dimorphism very clear in pronotum, protibiae and apical part of elytra. Females are generally less robust and with less transverse pronotum than males. The uroventrites $7^{\text {th }}$ and $8^{\text {th }}$, and spermatheca follows the overall model for the group.

\section{Note}

The great variability of this species led to the description of the subspecies zariquieyi Jeannel, 1936, later synonymized by Blas (1977), who observed that the differences correspond to intermediate forms and, moreover, the proximity of the different caves does not represent any real evidence of geographic isolation.

\section{Biology and Ecology}

Speonemadus escalerai is a subterranean species and, therefore, common in caves. It is mostly found in areas with small accumulations of bat guano, but also under stones or stalagmitic floors and in deep parts of caves (Blas 1989). Blas (1989), Giachino \& Vailati (1993) and Fresneda et al. (2007) also pointed out its presence in the Superficial Subterranean Habitat (MSS) (sensu Giachino \& Vailati 2010) in the karst area of Murcia.

\section{Distribution}

This species is distributed in the southeast Iberian Peninsula and colonizes caves of the provinces of Alicante, Murcia and Valencia in Spain (Fig. 32).

\section{Discussion}

\section{Speciation and biogeography of the $S$. escalerai-group}

The genus Speonemadus is distributed in the Western Mediterranean area. It is known from Algeria, Spain, Italy, Morocco, Portugal, Tunisia and the south of France, including the Mediterranean islands of Sicily and the Balearics.

Giachino \& Vailati (1993) stated that the four species groups, "vandalitiae", "transversostriatus", "escalerai" and "clathratus", diverged from from the original primitive lineage of the first group. 
The synapomorphies of the escalerai-group are: male protibia with keels, females with the apex of the elytra notched and serrated (Giachino \& Vailati 1993). The five species of this group are endemic to the Iberia Peninsula.

Scarce molecular data are reported for some species of Speonemadus (Fresneda et al. 2011): for $S$. angusticollis and $S$. bolivari, both of the escalerai-group, for $S$. clathratus, a widespread Iberian endemic, and for $S$. maroccanus, an ibero-Maghrebian species distributed in Morroco and in northeast Spain, the provinces of Cádiz, Granada and Málaga (Jeannel 1936; Coiffait 1954; Blas 1976, 1977, 1979, 1981, 1985, 1989; Bellés 1987; Fresneda et al. 2007, 2011; Giachino \& Vailati 1993; Tinaut 1998; Perreau 2000; Löbl \& Smetana 2004; Salgado et al. 2008). In the phylogenetic analysis given by Fresneda et al. (2011, fig. 74), S. angusticollis and S. bolivari appear in the same clade, while S. clathratus is closer to the previously mentioned species than to $S$. maroccanus. This observation, together with the similarity and consistency of the morphological characters, including very similar aedeagi, led us to think that the diversification of the species of the escalerai-group was recent and probably related to the climatic changes of the Pleistocene. In this climate change scenario, an ancestor capable of inhabiting different habitats became isolated underground, through the progressive environmental aridity at the surface in the southern Mediterranean region, therefore leading to a reduction of gene flow and the existence of allopatry in isolated populations in the climatic shelter provided by the subterranean spaces.

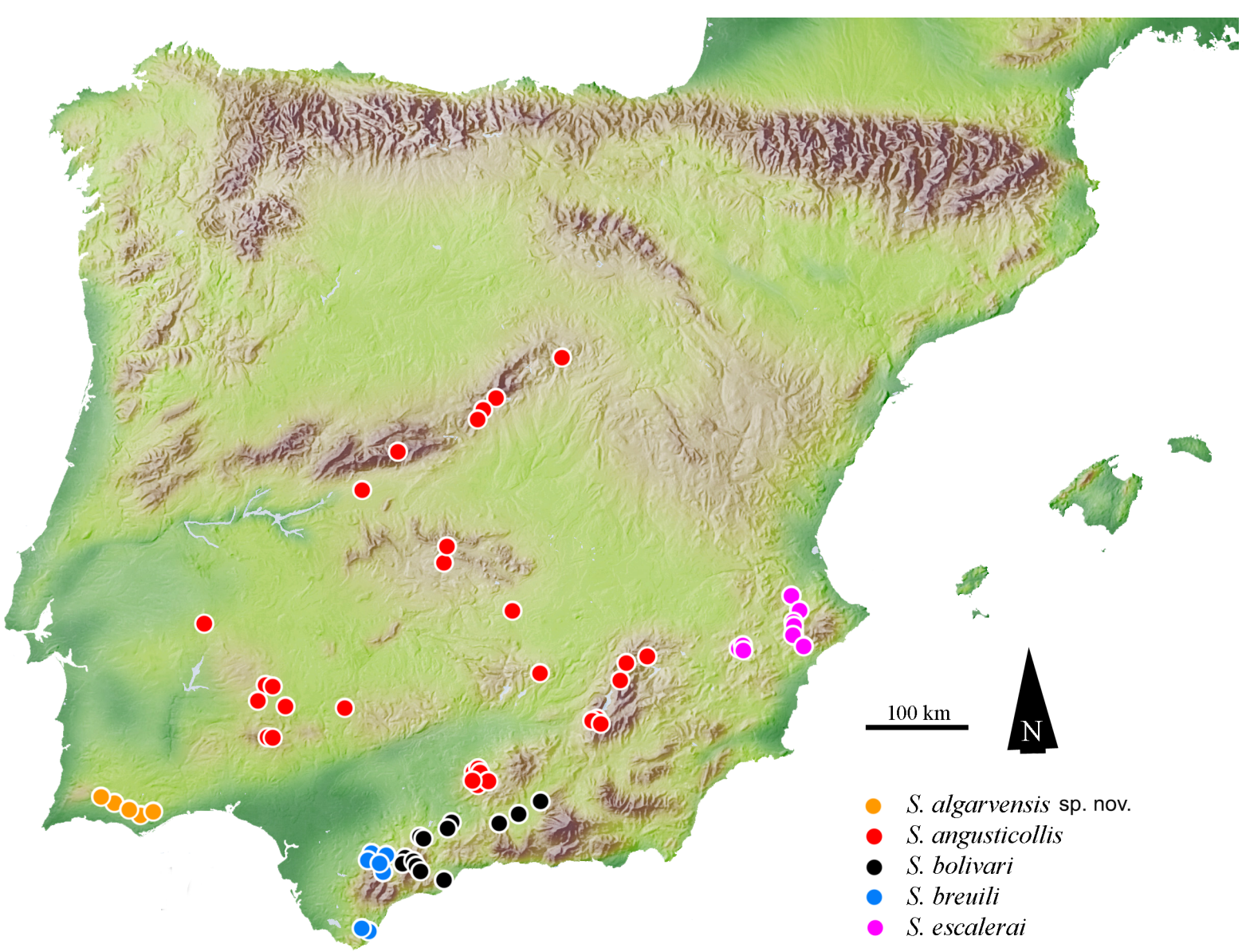

Fig. 32. Distribution of Speonemadus of the escalerai-group: S. algarvensis sp. nov., S. angusticollis (Kraatz, 1870), S. bolivari (Jeannel, 1922), S. breuili (Jeannel, 1922) and S. escalerai (Uhagón, 1898). 
The species of the escalerai-group and related species have a Betic-Rif distribution, where its origin might be located. There is some parallelism with the southern distribution of the Trechus fulvus-group (Carabidae), where multiple independent colonizations of the subterranean environment have been proposed based on the existence of troglomorphic species in clades that also include epigean species (Faille et al. 2014; Reboleira et al. 2009, 2010a).

The karst of the Algarve, in southern Portugal, is now considered a hospot for a subterranean-adapted fauna (Reboleira 2012), with a considerable increase in the number of species described over the last decade. Most of them are clearly relicts.

\section{Acknowledgements}

We express our gratitude to the Portuguese caving groups: NEUA, Geonauta, CEEAA and CEAE-LPN for their constant support in the field and to F. Regala. Also to Glòria Masó and Berta Caballero (Museo de Ciencias Naturales de Barcelona), and Pablo Barranco (Universidad de Almería), who kindly loaned specimens for comparison and to Josh Shaw for the English revision. ASPSR is funded by the Danish Council for Independent Research, ref. DFF-FNU 4002-00269.

\section{References}

Barranco P. 2005. Bioespeleología Bética. ENDINS 28: 81-88.

Bellés X. 1987. Fauna cavernícola i intersticial de la Península Ibèrica i les Illes Balears. Editorial Moll. CSIC-CSIC Press, Madrid.

Blas M. 1976. Coleópteros cavernícolas del distrito andaluz (Catopidae). Actas 4 Congreso Nacional de Espeleología: $157-160$.

Blas M. 1977. Contribución al conocimiento de los Anemadinae de la Península Ibérica. (Col. Catopidae).

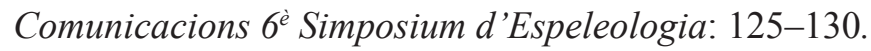

Blas M. 1979. Contribución al conocimiento de los Catopidae (excepto la subfam. Bathysciinae) de la Península Ibérica (Coleoptera Staphylinoidea). PhD Thesis, University of Barcelona, Barcelona.

Blas M. 1981. La subfamilia Anemadinae Jeannel (Col. Catopidae) i llur distribució geográfica actual. Treballs de l'Institució Catalana d'Història Natural 9: 155-156.

Blas M. 1985. Sobre los Catopidae de Portugal (Coleoptera). Boletim da Sociedade Portuguesa de Entomologia 1: 169-176.

Blas M. 1989. El género Speonemadus Jeannel y su distribución geográfica. (Col. Catopidae). Mémoires de Biospéologie 16: 135-140.

Coiffait H. 1954. Catopidés récoltés en Andalousie. Description de trois formes nouvelles. Notes biospéologiques 9 (1): 21-24.

De Kesel A. \& Haelewaters D. 2014. Laboulbenia slackensis and L. littoralis sp. nov. (Ascomycota, Laboulbeniales), two sibling species as a result of ecological speciation. Mycologia 106 (3): 407-414. http://dx.doi.org/10.3852/13-348

Enghoff H. \& Reboleira A.S.P.S. 2013. Subterranean species of Acipes Attems, 1937 (Diplopoda, Julida, Blaniulidae). Zootaxa 3652 (4): 485-491. http://dx.doi.org/10.11646/zootaxa.3652.4.6

Faille A., Andújar C., Fadrique F. \& Ribera I. 2014. Late Miocene origin of an Ibero-Maghrebian clade of ground beetles with multiple colonizations of the subterranean environment. Journal of Biogeography 41: 1979-1990. http://dx.doi.org/10.1111/jbi.12349 
Fresneda J. 2008. Datos de distribución de Speonemadus bolivari (Jeannel, 1922) (Coleoptera, Leiodidae, Cholevinae, Anemadini). Monografías Bioespeleológicas 3: 13-15.

Fresneda J., Cárdenas A.M., Castro A., Lencina J.L., López-Colón J.I. \& Baena. M. 2007. Nuevos datos de los Cholevidae en la Península Ibérica (Coleoptera). Boletín de la Asociación española de entomología 31(3-4): 187-214.

Fresneda J., Grebennikov V. \& Ribera I. 2011. The phylogenetic and geographic limits of Leptodirini (Coleoptera: Leiodidae: Cholevinae), with a description of Sciaphyes shestakovi sp.n. from the Russian Far East. Arthropods Systematics \& Phylogeny 69 (2): 99-123.

Fuente J.M. 1925. Catálogo sistemático-geográfico de los Coleópteros observados en la Península Ibérica, Pirineos propiamente dichos y Baleares. Boletín de la Real Sociedad Entomológica de España vii (2-3) [1924]: 93-117.

Giachino P.M. \& Vailati D. 1993. Revisione degli Anemadinae. Museo Cívico di Scienze Naturali di Brescia. Monografie di "Natura Bresciana" 18: 1-314.

Giachino P.M. \& Vailati D. 2010. The subterranean environment. Hypogean life, concepts and collecting techniques. WBA Handbooks 3, World Biodiversity Association, Verona.

Haelewaters D., Zhao S. Y., Kesel A. D., Handlin R. E., Royer I.R., Farrell B.D. \& Pfister D.H. 2015. Laboulbeniales (Ascomycota) of the Boston Harbor Islands I: species parasitizing Coccinellidae and Staphylinidae, with comments on typification. Northeastern Naturalist 22(3): 459-477. http://dx.doi. org/10.1656/045.022.0304

ICZN. 2016. International Code of Zoological Nomenclature. [online]. Available from http://www.iczn. org/iczn/index.jsp [accessed 4 Feb. 2016].

Jeannel R. 1922. Silphidae Catopinae (Coléoptères) (deuxième série) avec une étude phylogénique et paléogéographique de la sous-famille. Archives de Zoologie expérimentale et générale 61 (1): 1-98.

Jeannel R. 1936. Monographie des Catopidés. Mémoires du Muséum national d'Histoire naturelle 1 (1). Muséum national d'Histoire naturelle, Paris.

Jeannel R. 1941. Premières explorations des grottes du Portugal par M.A. de B. Machado, Coléoptères. Publicações do Instituto de Zoologia "Augusto Nobre" 4: 5-15.

Kraatz G. 1870. Choleva angusticollis Kraatz n. sp. In: Heyden L. von (ed.) Entomologische Reise nach dem südlichen Spanien der Sierra Guadarrama und Sierra Morena, Portugal und den Cantabrischen Gebirgen: 98-99. Entomologischer Verein in Berlin, Berlin.

Löbl I. \& Smetana A. 2004. Catalogue of Palaearctic Coleoptera. Volume 2. HydrophiloideaHisteroidea-Staphylinoidea. Apollo Books, Vester Skerninge.

Marseul S. 1884. Précis des genres et espèces de la tribu des Silphales de l'ancien-monde. L'Abeille 22: $1-204$.

Mateu J. 1953. Revision de los Ceuthosphodrus (s. str.) cavernícolas de la península ibérica. Actes I Congrès International de Spéléologie 3 (3): 113-124.

Pérez T. 2014. Insectos colectados en cuevas de la Colección de Artrópodos de la Estación Experimental de Zonas Áridas (C.S.I.C.) de Almería (España). Arquivos Entomolóxicos 12: 229-236.

Pérez T. 2015. Catálogo de invertebrados citados en cuevas, simas y minas de Andalucía. Monografías Bioespeleológicas 9: 1-97.

Pérez T. \& Pérez A. 2006. Estudios Bioespeleológicos en la Cueva Secreta del Sagreo, La Iruela (Jaén). Monografias Bioespeleológicas 1: 1-13. 
Pérez A. \& Tinaut A. 2005. Bioespeleología en la provincia de Jaén. Espeleo 17: 1-10.

Pérez T., Pérez A., Pérez J. \& García F. 2013. La cueva Secreta del Sagreo (La Iruela, Jaén, sur de España), una cavidad con historia en Jaén. Espeleo-Tema 24 (1): 31-39.

Perreau M. 2000. Catalogue des Coléoptères Leiodidae Cholevinae et Platypsyllinae. Mémoires de la SEF 4, Société entomologique de France, Paris.

Reitter E. 1885. Bestimmungs-Tabellen der europäischen Coleopteren, 12 Necrophaga. Verhandlungen des naturforschenden Vereines in Brünn 23: 3-122.

Reboleira A.S.P.S. 2007. Os coleópteros (Insecta, Coleoptera) cavernícolas do maciço calcário Estremenho: uma aproximação à sua biodiversidade. MSc thesis. University of Aveiro, Portugal.

Reboleira A.S.P.S. 2012. Biodiversity and conservation of subterranean fauna of Portuguese karst. PhD thesis. University of Aveiro, Portugal.

Reboleira A.S.P.S. \& Enghoff H. 2013. The genus Boreviulisoma Brolemann, 1928-an Iberian-N African outlier of a mainly tropical tribe of millipedes (Diplopoda: Polydesmida: Paradoxosomatidae). Zootaxa 3646 (5): 516-528. http://dx.doi.org/10.11646/zootaxa.3646.5.2

Reboleira A.S.P.S. \& Enghoff H. 2014. Millipedes (Diplopoda) from caves of Portugal. Journal of Cave and Karst Studies 76 (1): 20-25. http://dx.doi.org/10.4311/2013LSC0113

Reboleira A.S.P.S. \& Ortuño V.M. 2011. Description of the larva and female genitalia of Trechus gamae with data on its ecology. Bulletin of Insectology 64 (1): 43-52.

Reboleira A.S.P.S., Gonçalves F. \& Serrano A. 2009. Two new species of cave-dwelling Trechus Clairville of the fulvus-group (Coleoptera, Carabidae, Trechinae) in Portugal. Deutsche Entomologische Zeitschrift 56 (1): 101-107. http://dx.doi.org/10.1002/mmnd.200900009

Reboleira A.S.P.S., Ortuño V.M., Gonçalves F. \& Oromí P. 2010a. A hypogean new species of Trechus Clairville, 1806 (Coleoptera, Carabidae) from Portugal and considerations about the T. fulvus species group. Zootaxa 2689: 15-26.

Reboleira A.S.P.S., Sendra A., Gonçalves F. \& Oromí P. 2010b. The first hypogean dipluran from Portugal: description of a new species of the genus Litocampa (Diplura: Campodeidae). Zootaxa 2728: 50-56.

Reboleira A.S.P.S., Zaragoza J., Gonçalves F. \& Oromí P. 2010c. Titanobochica, surprising discovery of a new cave-dwelling genus from southern Portugal (Arachnida: Pseudoscorpiones: Bochicidae). Zootaxa 2681: 1-19.

Reboleira A.S.P.S., Borges P., Gonçalves F., Serrano A.R.M. \& Oromí P. 2011a. The subterranean fauna of a biodiversity hotspot region-Portugal: an overview and its conservation. International Journal of Speleology 40 (1): 23-37. http://dx.doi.org/10.5038/1827-806X.40.1.4

Reboleira A.S.P.S., Gonçalves F. \& Oromí P. 2011b. On the Iberian endemic subgenus Lathromene Koch (Coleoptera: Staphylinidae: Paederinae): description of the first hypogean Domene Fauvel, 1872 from Portugal. Zootaxa 2780: 48-56.

Reboleira A.S.P.S., Gonçalves F., Oromí P. \& Mendes L.F. 2012a. Squamatinia algharbica gen. n. sp. n., a remarkable new Coletiniinae silverfish (Zygentoma: Nicoletiidae) from caves in southern Portugal. Zootaxa 3260: 33-46.

Reboleira A.S.P.S., Zaragoza J.A., Gonçalves F. \& Oromí P. 2012b. Lusoblothrus, a new syarinid pseudoscorpion genus (Arachnida) from Portugal, occupying an isolated position within the Holarctic fauna. Zootaxa 3544: 52-62. 
Reboleira A.S.P.S., Gonçalves F. \& Oromí P. 2013. Literature survey, bibliographic analysis and a taxonomic catalogue of subterranean fauna from Portugal. Subterranean Biology 10: 51-60. http:// dx.doi.org/10.3897/subtbiol.10.4025

Reboleira A.S.P.S., Gonçalves F., Oromí P. \& Taiti S. 2015. The cavernicolous Oniscidea (Crustacea: Isopoda) of Portugal. European Journal of Taxonomy 161: 1-61. http://dx.doi.org/10.5852/ejt.2015.161

Ribera C. 1970. Resultados faunísticos de la campaña Serranía de Ronda. In: Actas I Congreso Nacional de Espeleología: 123-129. Editorial Ayuntamiento, Barcelona.

Ribera I., Fresneda J., Bucur R., Izquierdo A., Vogler A.P., Salgado J.M. \& Cieslak A. 2010. Ancient origin of a Western Mediterranean radiation of subterranean beetles. BMC Evolutionary Biology 10: 29. http://dx.doi.org/10.1186/1471-2148-10-29

Sáez J. \& Blanco J.M. 2010. Los colévidos epigeos (Coleoptera, Leiodidae, Cholevinae) de la Sierra de Tudía (Badajoz, Extremadura, España). Boletín de la Sociedad Entomológica Aragonesa 47: 357-361.

Salgado J.M., Blas M. \& Fresneda J. 2008. Coleoptera, Cholevidae. Fauna Ibérica, vol. 31, Museo Nacional de Ciencias Naturales, CSIC, Madrid.

Szymczakowski W. 1970. Contribution à la connaissance des Catopidae (Coleoptera) paléarctiques. Acta Zoologica cracoviensia 15 (4): 259-282.

Tinaut A. 1998. Artrópodos terrestres de las cavidades andaluzas. Zoologica Baetica 9: 3-28.

Uhagón S. 1890. Ensayo sobre las especies españolas del grupo "Cholevae". Anales de la Sociedad española de Historia natural 19: 15-96.

Uhagón S. 1898. Adiciones a mi "Ensayo sobre las especies españolas del grupo "Cholevae". Anales de la Sociedad española de Historia natural, 7(2), 27". Actas de la Sociedad española de Historia natural 1: $117-126$.

Zaragoza J.A. \& Sendra A. 1988. Fauna cavernícola de la provincia de Alicante. Volumen 3: Fauna, Flora, Ciencia y Medicina. Instituto de Estudios Juan Gil-Albert. Ed. Diputación Provincial de Alicante.

Manuscript received: 4 February 2016

Manuscript accepted: 13 July 2016

Published on: 19 January 2017

Topic editor: Gavin Broad

Desk editor: Laurence Bénichou

Printed versions of all papers are also deposited in the libraries of the institutes that are members of the EJT consortium: Muséum national d'Histoire naturelle, Paris, France; Botanic Garden Meise, Belgium; Royal Museum for Central Africa, Tervuren, Belgium; Natural History Museum, London, United Kingdom; Royal Belgian Institute of Natural Sciences, Brussels, Belgium; Natural History Museum of Denmark, Copenhagen, Denmark; Naturalis Biodiversity Center, Leiden, the Netherlands. 